\title{
Co-operation, Contestation and Complexity in Post-Conflict Security Sector Reform
}

Nadine Ansorg, University of Kent and GIGA German Institute of Global and Area Studies, \& Eleanor Gordon, Monash University

Security Sector Reform (SSR) remains a key feature of peacebuilding interventions and is usually undertaken by a state alongside national and international partners. External actors engaged in SSR tend to follow a normative agenda that often has little regard for the context in post-conflict societies. Despite recurrent criticism, SSR practices of international organisations and bilateral donors often remain focused on state institutions, and often do not sufficiently attend to alternative providers of security or existing normative frameworks of security. This article provides a critical overview of existing research and introduces the special issue on "Co-operation, Contestation and Complexity in Post-Conflict Security Sector Reform". We explore three aspects that add an important piece to the puzzle of what constitutes effective SSR. First, the variation of norm adoption, norm contestation and norm imposition in post-conflict countries that might explain the mixed results in terms of peacebuilding. Second, the multitude of different security actors within and beyond the state which often leads to multiple patterns of co-operation and contestation within reform programmes. And third, how both the multiplicity of and tension between norms and actors further complicate efforts to build peace or, as complexity theory would posit, influence the complex and non-linear social system that is the conflict-affected environment. 


\section{Co-operation, Contestation and Complexity in Post-Conflict Security Sector Reform}

In the aftermath of conflict, Security Sector Reform (SSR) continues to be widely regarded by policy makers and practitioners as one of the most vital tasks in the peacebuilding endeavour (Jackson 2018; Sedra 2018, 2010; UN 2013, 2008). While there is no agreed definition, for policymakers and practitioners, SSR typically refers to the reform, construction or reconstruction of security and justice sector institutions, including oversight and management bodies (DCAF 2015a; Sedra 2010; Wulf 2011). There remains debate, however, on whether or not SSR incorporates the justice sector; whether transformation, development or construction might be more appropriate terms than 'reform' given the comprehensive nature of most reform efforts; whether the principles inherent to SSR - accountability, equality, local ownership - are shared or can ever be fully adhered to; and who are or should be the main agents of these very reforms (DCAF 2015b; Sedra 2010; Donais 2018). SSR is usually undertaken by a state alongside national and international partners, with the ostensible aim of improving the provision of safety, security and justice to its citizens, in recognition of security being a precursor to long term peace (Jackson and Bakrania 2018; Andersen 2011). Underpinning SSR is the importance of improving Security Sector Governance (SSG), ensuring security sector institutions are accountable, affordable, effective and responsive to the needs of the people (DCAF 2015b).

Disarmament, demobilisation and reintegration (DDR) of former combatants is often interrelated with SSR. DDR is fundamentally a process through which armaments are removed from former combatants, who are also removed from military structures and assisted in reintegrating into civilian life, and sometimes into state security institutions (Lamb and Stainer 2018). Both DDR and SSR are highly political exercises with normative implications, involving the redistribution of power and generally aiming to re-establish the state's monopoly of the legitimate use of force. DDR and SSR can also be mutually reinforcing with, for instance, former non-state armed actors being integrated into state security institutions, which can help rebuild trust between formerly warring parties as well as dis-incentivise potential spoilers by providing a stake in the state security structures and the prospects of long-term employment (McFate 2010). Conversely, where DDR falters, due to resistance, distrust or non-compliance, the prospects for successful SSR are inevitably compromised (Knight 2010).

This special issue includes articles which address both SSR and DDR, and the relationship between the two. It does this because SSR and DDR are so integrally related and because they both fundamentally resonate with the three key issues addressed in this collection. First, the question of norm adoption, contestation and imposition during reform of the security sector, particularly related to claims for the monopoly of the legitimate use of force. Second, the multitude of different security actors which can lead to multiple patterns of co-operation and contestation within programmes. And third, the consequent complexity which can compromise programmatic success and, thus, prospects of long-term peace. The aim of this special issue is to reveal patterns of norm adoption, contestation and imposition, as well as patterns of co-operation and confrontation between involved actors of SSR, and how these might impact the extent to which SSR programmes are effective in meeting their intended objectives of contributing to long-term peace and stability. In so doing, the articles in this special issue identify ways in which the challenges resulting from the multiplicity of and tension between norms and actors can be best addressed. The articles also 
ask how SSR programmes can be designed and implemented in environments where there are multiple levels of security arrangements that determine patterns of security and insecurity. Findings of the studies in this collection will contribute to previous research on SSR and DDR, as outlined in this introduction, and help inform practitioners' considerations on politically-informed SSR programming, particularly external actors engaged in reform efforts in societies and cultures outside their own.

Internationally-led SSR programmes are often guided by measures of "success" and "failure" that are defined according to "the classical Weberian model of statehood as an exclusive template" (Schroeder and Chappuis 2014: 134). This might be helpful for limited projects that strive for certain benchmarks to evaluate progress. However, it turns out to be unhelpful when donors insufficiently contextualise these templates to the needs and wishes of national governments and local communities. Beyond these generic templates, one obvious way of measuring the impact of SSR programmes is the absence of direct, physical violence that has been characteristic of the armed conflict. Yet, as Cheng et al. (2018: 26ff.) elaborate, policymakers and practitioners need to disaggregate different forms of violence to be best able to address them: Even if large-scale forms of competitive violence that were persistent throughout the war have ceased to exist, other forms of violence such as embedded or permissive violence might still be prevalent and even accepted for the stability of a post-conflict country.

Indeed, some forms of violence are sustained across war and peace; where power relations, structures and norms remain unchanged, violence against women can remain widely prevalent (Grady 2010; Duncanson 2016). Some forms of violence can increase after the end of armed conflict, such as domestic violence, with peace bringing "violence from the battlefield into the home" (Call 2007: 392) in part as a result of returning traumatised, male combatants, with little job prospects and "resentment at the opportunities and (usually obligatory) mobility women experienced during wartime" (Call 2007: 392). Some new forms of violence can occur in conflictaffected environments, where new opportunities and risks arise (such as sexual exploitation and abuse by peacekeepers, and trafficking and other forms of organised crime cf. Grady 2010; True 2012). Other forms of violence become less visible, but no less pernicious, as the focus is on public and often political forms of violence (Laliberté, 2016). Recognising the many forms of violence and other harms that persist in post-conflict environments clearly has an impact on determinants of success and failure in respect of SSR programmes.

The main assumption of this article, in line with recent research on SSR in post-conflict countries (e.g. Jackson 2018; Donais 2018; Sedra 2018; Detzner 2017), is that there is not a single template of what the outcome of SSR should look like. Rather, there exist different models of a security sector that are context-specific and that foster a sense of peace and order for local communities and that are accessible to all parts of the society. The article thus links to central debates in the SSR literature in the past years: the need to include local, non-state actors has been acknowledged and studied (cf. Donais 2018; Furuzawa 2018; Gordon 2014) and there have been multiple analyses of hybrid and integrative security models (cf. Albrecht 2018; Schroeder et al. 2014). Equally, there have been attempts by international donors, in part in response to SSR scholarship, to include into SSR policy and guidelines actors beyond those at the level of the state (e.g. UN 2014). While the inclusion of local actors and the attention to local norms is uncontested nowadays, this article and 
the special issue move on to more fine-grained analysis of the patterns of variations that can occur within this second generation of security sector reform (cf. Jackson 2018) and that might lead to more or less accepted modes of security governance and to more or less security for local communities. For example, while largely locally-driven efforts such as in South Africa in defence, police and intelligence reform (cf. Africa 2008) might be desirable, a conundrum exists in particular in the most severe conflict cases: due to years of mistrust and violence between former warring parties the immediate co-operation of former adversaries might not be feasible. Hence, international actors might have to act as third-party guarantors against a renewed outbreak of violence and support any efforts to reform the security sector (Walter 2002). Given the findings of previous research, this special issue thus asks under what conditions is the ownership of local actors and the attendance to existing norms more feasible and leads to the creation of an accepted and sustainable security sector, and when does it create a fragile peace that results in a renewed outbreak of violence?

In this collection, we look at examples of where security sector reform has followed the most severe cases of conflict; cases such as East Timor, Uganda, El Salvador, Democratic Republic of Congo and Nepal. The main actors in SSR efforts in these countries have been international donors, including the UN and World Bank, which have long dominated the normative debate about SSR since its beginning in the late 1990s. There have also been also other, bilateral donors which have their own agendas that might differ from the overarching framework promoted by UN and World Bank - one might just think about the US and their overtly military reading of SSR (Albrecht, Stepputat, \& Andersen, 2010); or the UK, Germany, Netherlands and the Scandinavian countries who started, in recent years, to also include, to some extent, civil society and non-state actors into their design and implementation of SSR programmes (DCAF ISSAT G. C., 2018). South-south cooperation has also increased in recent years, such as the involvement of the African Union Mission in Somalia (AMISOM) in providing the training and equipment of Somali security forces (DCAF ISSAT G. C., 2017). While we acknowledge these efforts, we focus our discussion in this article, and the articles we introduce in this special issue, on large international donors that continue to dominate large SSR programmes.

The articles in this special issue connect to current findings and address three inter-related aspects which current debates on SSR consider to be fundamental to the extent to which SSR programmes are effective (e.g. Jackson 2018; Donais 2018; Sedra 2018; Detzner 2017). Firstly, the variation of norm adoption, contestation and imposition in post-conflict countries. Secondly, the multitude of different actors engaged in reform efforts beyond the level of the state that might lead to multiple patterns of contestation and co-operation between actors. Finally, how both the multiplicity of and tension between norms and actors further complicates efforts to build peace. These three aspects have the potential to significantly impact how security sector institutions are developed, as well as regarded and accepted by local communities and, consequently, the extent to which these institutions are effective and sustainable.

This introductory article briefly draws from the application of complexity theory to peacebuilding (de Coning 2018) to underscore how problematic it can be to influence social systems - particularly post-conflict social systems - which are already complex, dynamic and non-linear. Complexity theory has been applied to peacebuilding (de Coning 2018) but, as yet, not specifically to the study 
of SSR and DDR. Drawing from complexity theory, and the insights in the articles in this collection, we can see how proliferation of and contestation between actors, and between their normative positions, may question assumptions of "success" and "failure" of international donors when designing and implementing SSR and DDR programmes.

In introducing this special issue on "Co-operation, Contestation and Complexity in Post-Conflict Security Sector Reform", this article provides a critical overview of existing research on fundamental aspects in the study of SSR. It also provides the framework for the articles and presents the conceptual narrative of the special issue. This introductory article begins by discussing the conceptual-contextual divide in SSR programmes (Chanaa 2002; Jackson and Bakrania 2018; Podder 2013), focussing specifically on the continued state-centred focus of SSR (Jackson 2018; Jackson and Bakrania 2018; Sedra 2018), and situates the debates within the wider field of critical peacebuilding. It then moves on to a discussion of the role of norm diffusion - including imposition, contestation, and adaption - in SSR, DDR and broader peacebuilding efforts. As norms are created, changed, and contested by actors, we will then move on to a discussion of the role of different actors engaged in SSR and DDR, before we conclude with a discussion of the complexity and political dimensions of SSR and its implications for the establishment of peace in conflict-affected environments.

\section{SSR's Normative Agenda}

The ostensible aims of internationally-led SSR, at least in established policy guidance (OECD 2007, 2005; UN 2014), are deeply normative in character and oriented at an ideal type of Weberian state (Schroeder and Chappuis 2014). They usually include helping the central state achieve a monopoly on the legitimate use of force, democratic oversight over the security sector, the protection of human rights, and transparent and accountable processes. In practice, internationally-led SSR programmes oftentimes side-line the normative agenda in favour of expediency, cost and clarity: oversight bodies - and broader efforts to promote governance, accountability and transparency often receive less attention and less resources than the core security sector institutions they are to hold accountable (Jackson 2018; Sedra 2018); human rights and gender equality are often reduced to a day's awareness training or a footnote in a report (Ansorg and Haastrup 2018). The statecentred focus of SSR as contained in these core texts does, however, continues to inform practice. Indeed, as Jackson (2018: 2) argues, a focus on state effectiveness and technical train-and-equip programmes have tended to eclipse "the strong normative agenda of democracy and human rights".

Despite recurrent criticism of the often state-centred nature of SSR, the prevailing focus of many externally-driven SSR programmes on building the capacity and effectiveness of state institutions suggests that SSR remains central to the statebuilding exercise, which continues to remain central to peacebuilding (Jackson 2011). Broadly speaking, the threat of the non-state to many countries, specifically in the post-9/11 world, has reaffirmed the importance of a strong state (Duffield 2007), and particularly building the capacity of the security sector as "the defining element of modern statehood" (Benedix and Stanley 2008: 97). Internationally-led SSR programmes, thus, continue to focus on state institutions - reforming, constructing or reconstructing them, building their capacity, training and equipping their staff, amending or drafting legislative and policy frameworks 
to facilitate their work, creating structures to co-ordinate and enhance their efforts (Baker and Scheye 2007; Gordon 2014; Jackson 2011). In recent years there have been some efforts on the part of international actors engaged in SSR to support and build the capacity of non-state security and justice providers and promote a hybrid approach to SSR (DCAF 2018; Commission 2016). Nonetheless, in many internationally-led SSR programmes there continues to be little effort to look beyond the level of the state, at the relationship between the state and its people, or how local-level agency impacts SSR (Andersen 2012; Ansorg 2017; Donais and Knorr 2013; Jackson 2010, 2011, 2018). This is despite SSR literature underscoring the importance of public support and confidence in the state, which lends the state legitimacy, which is critical to state effectiveness (Jackson 2010) and SSR literature advocating for the integration of a social contract perspective to SSR (Knight 2009).

The state-centred focus of SSR may come of no surprise to civil servants and policy-makers; after all, it is state actors and international organisations consisting of states who promote this view. Yet, what might be seen as ideal in international organisations or leading donor countries, may not in non-OECD countries from the Global South. African-driven SSR efforts have only materialised in recent years with the "African Union Policy Framework on Security Sector Reform" (African Union Commission 2014) and attempts to develop an ECOWAS framework on SSR (Ebo 2007). However, the debate on the concepts and content of SSR programmes continues to be driven by international donors such as UN or World Bank, which often take the lead in SSR programmes in countries as diverse as Liberia (Malan, 2008), DR Congo (Mobekk, 2009), or Kosovo (LemayHébert 2013). The neoliberal peacebuilding project which continues to place the state at the centre of peacebuilding endeavours, and enshrines within it all prospects of long-term peace, serves to reinforce dominant power relations; marginalising the non-state and, with it, prospects of peace that might be more meaningful to all beyond dominant and elite groups (Donais 2018; Jackson $2010,2011,2018)$. Moreover, power relations on the international stage are also reinforced through reification of the state. Indeed, neoliberal peacebuilding may be regarded as part of colonialist endeavours; strengthening the state but only as a reflection of how states look and what states do in the Global North, with little consideration given to local context beyond the national level (Ansorg and Kurtenbach 2017; Chandler 2000; Duffield 2007; Richmond 2006). Unsurprisingly, political elites of target states might themselves apply the donor-centred language of capacity and state-building, often driven by the desire to increase rents and economic opportunities as part of the political bargaining in the immediate post-conflict period (Cheng et al. 2018). And, of course, political elites of target states also have a vested interest in maintaining power rather than divesting it to a wide variety of non-state actors (Donais, 2017).

The irony remains, of course, that there isn't a singular vision of what works in terms of security sectors. Moreover, even the realities of security sectors in developed countries are far away from this ideal the donor agencies would like to see promoted in conflict-affected contexts. In the US, for example, the police is highly racially biased, to the point that "the probability of being \{black, unarmed, and shot by police\} is about 3.49 times the probability of being \{white, unarmed, and shot by police\} on average" (Ross 2015: n.p.). Institutional racism continues to be a problem of the British judiciary: the Lammy review, a recent independent review into the treatment of, and outcomes for Black, Asian and Minority Ethnic individuals in the criminal justice system, led by David Lammy, MP, shows that BAME individuals still face bias, including overt discrimination, 
in parts of the justice system (Lammy Review 2017). And a UN panel concluded that German security and government agencies discriminate against people of African descent, allowing for widespread institutional racism (OHCHR 2017). Donors, thus, have to reflect on and discuss different normative avenues of promoting the reform of security sector abroad, while at the same time acknowledging that there is not an exclusive template of statehood and SSR in a post-conflict country.

The fact that state-centred SSR programmes continue to dominate despite a widely-acknowledged mixed record of success further underscores the irony (Jackson 2018; Jackson and Bakrania 2018; Sedra 2018). Even in examples generally considered to be successful (cf. Detzner 2017), there have been aspects which have had sub-optimal or counterproductive outcomes. In Sierra Leone, for example, a heavy externally-driven process facilitated decentralisation, including in the area of security, which contributed to peace at the local level but failed to affect power dynamics between local chiefs and national political elites which poses a potentially greater threat to a more devolved form of governance (Nickson and Cutting 2016). The same can be said of DDR programmes, with a mixed record of success including within individual programmes generally considered to have met agreed outcomes. For instance, the DDR process in Mozambique and subsequent peacebuilding throughout the early 1990s is generally considered to have been thorough and effective (cf. Sabaratnam 2017: 9). Yet, a recent outbreak of violence after the elections in 2014 reveals a lack of effective post-war justice mechanisms and resentment particularly among previous members of RENAMO (Resistência Nacional Moçambicana) regarding the perceived lack of representation (Sabaratnam 2017: 9). This shows that large-scale competitive violence has deceased, but the causes of conflict are not tackled sufficiently, so that the risk of renewed outbreak of violence remains.

Despite these mixed results and the afore-mentioned paradoxes, the agenda of international donors and the state-centric approaches in their programmes continue to be driven by normative aims that only marginally relate to specific contexts on the ground. There have been missed opportunities to improve the record of SSR through thorough investigation and understanding why sub-optimal results have occurred despite best efforts and investment of significant resources (cf. Denney and Valters 2015). In these internationally-led programmes, there have been similar missed opportunities to build upon effective SSR practices, as a result of limited evaluation - or engagement with exiting evaluations and analysis - as well as translation and application of models without sufficient context analysis (Germann 2002; Jackson and Bakrania 2018; Schroeder 2010; Sedra 2017, 2018). With this special issue, we aim to contribute to understanding the varied patterns of norm adoption and different levels of inclusion of local actors that might lead to the mixed results of SSR programmes.

\section{Contesting, adopting and adapting norms on SSR}

As outlined above, international and national concepts and guidelines of security sector reform continue to be driven by a normative agenda focused on human rights, rule of law, good 
governance, and democratic values. Yet, previous research has shown that these guiding norms of SSR agendas are only marginally implemented in practice. Already in 2002, Chanaa revealed a "conceptual-contextual divide" between SSR frameworks and the contextual realities in conflictaffected countries. This idea has been evidenced by numerous case studies on major SSR programmes in the past fifteen years: Findings from a few over-studied cases - including Sierra Leone (e.g. Albrecht and Jackson 2014a, 2014b), Liberia (e.g. Podder 2013), Kosovo (e.g. LemayHerbert 2013; Holohan 2016), Bosnia and Herzegovina (Marijan 2017; Klopfer et al. 2012), Afghanistan (Sedra 2014, 2007; Ayub et al. 2009), or Iraq (Rathmell 2005; Sedra 2007) - have shown that SSR in practice is often a technical exercise that focuses on building the capacity of security sector institutions, but lacks co-ordinated and comprehensive efforts to develop local institutions that are accepted by the population, resulting in a clear gap between policy and practice (Gordon 2014; Albrecht and Jackson 2014a; Jackson 2018; Sedra 2018). Short-term stability is then often prioritised over the long-term development of institutions, often only marginally attending to the conceptually prioritised norms.

The normative critique in the SSR literature can be linked to a wider debate on challenges in statebuilding and peacebuilding that engages in a comprehensive critique of the international peacebuilding agenda and calls for a better inclusion and recognition of the agency of local populations in post-conflict peacebuilding endeavours. In particular, scholars from the critical peacebuilding school such as Richmond (2011), Mac Ginty (2010), Heathershaw (2008), and Paffenholz (2010) have pointed out the importance of greater inclusion of civil society, local authorities and other actors beyond the level of the state, and the potential of hybrid governance systems for long-term peace and stability.

There are two aspects that are of importance here. On the one hand, internationally-driven SSR programmes are often guided by a very specific normative framework that comes with the above mentioned "classical Weberian model of statehood as an exclusive template" (Schroeder and Chappuis 2014: 134) for the security sector. On the other hand, in practice, the implementation of these normative guidelines at times falls victim to expediency, cost and clarity (Jackson 2018; Sedra 2018). As a consequence, specific local contexts and existing security norms are often neglected in the process of both the design and implementation internationally-driven SSR programmes.

In terms of SSR scholarship, some questions continue to remain unanswered in particular from a post-colonial critique of persistent Eurocentric concepts. For instance, given the assumption that SSR concepts and programmes come with certain normative assumptions regarding democracy, rule of law and human rights, what is the context under which norms get side-lined in the dynamic and non-linear environment of post-conflict countries, and when are they maintained as guiding principles? If they are maintained within a SSR programme, what are the patterns under which these norms get imposed, adopted, adapted, contested? Under which circumstances is it more likely that conflict-affected areas will adopt democratic norms, and when is there resistance towards certain aspects? What implications does this have for the states emerging from conflict? What are the consequences of these developments for people who suffer insecurity, and for those responsible for managing or establishing security? 
States vary in their adoption of the normative goals of SSR. As indicated by previous research, in some cases domestic actors enhance their security capacities through external training or infrastructural assistance, "but without implementing overarching norms and rules to govern the use of force" (Schroeder, Chappuis, and Kocak 2014: 218). In others cases, domestic actors nominally institutionalize specific norms, "but fail to implement appropriate organizational structures and capacities" (Schroeder, Chappuis, and Kocak 2014: 218).

The most obvious and most discussed pattern of norm diffusion is probably the one of imposition of norms, which is widely debated in the literature on critical peacebuilding. The idea of norm imposition lies at the very heart of critiques of peacebuilding and SSR programmes as neoliberal and at times neo-colonial endeavour of international actors (Lemay-Herbert 2013; Chandler 2006). Particularly in cases where international actors take on a more directive role, for example in the $\mathrm{DRC}^{1}$, some norms are rather imposed or coerced onto the society of the target state, often without much attention towards local realities on the ground - or the "context" in which SSR might be implemented (see Chanaa 2002). In addition, recipients of SSR reform in post-conflict countries often experience the processes of norm diffusion as "heavily shaped by memories of colonialism and exploitation" (Baaz and Stern 2017: 208), thus perpetuating neo-colonial structures by way of SSR missions. The states that evolve out of these programmes are then often only fragile constructs of an idea of a liberal state, with elections, organisations such as the police, governments, or political parties, but without being established or even accepted by the local population: "In reality, what external agents do is set up organizations, not institutions" (Ottaway, 2002: 1004). These institutions, however, often do not provide rules and procedures that correspond with the reality of relevant actors on the ground.

But patterns of norm diffusion at times go beyond a mere imposition; norms might be adopted and subsequently adapted by national governments or non-state actors, or an imposition of norms might be contested. Such patterns in a post-conflict context might be informed by debates on similar topics in other areas of International Relations. For example, in his works about norm localization and institutional change in Asian regionalism, Acharya (2004) discusses the idea of "localisation" of foreign norms into local norms and traditions. Achrya defines "localisation" as "the active construction (through discourse, framing, grafting, and cultural selection) of foreign ideas by local actors, which results in the former developing significant congruence with local beliefs and practice" (Acharya 2004: 245). Eventually, ideas and norms need to be accepted by the local population. This entails that local norms are not replaced, but foreign norms are adapted to fit local beliefs and practices, thus creating resonance. A similar argument is made by Checkel when analysing the influence the European human rights regime has on domestic politics in Germany (Checkel 1999). His focus lies on local "norm-takers" (Checkel 1999: 91) such as local elites, who voluntarily incorporate foreign ideas into local norms and traditions.

Drawing on assumptions from social psychology for her research on nuclear non-proliferation, Rublee $(2008$; 2009) points towards the importance of "norm entrepreneurs" for the appropriation of norms. She finds that the potency of norm transmission is influenced by three conditions

1 For an excellent account of subjectification and (lack of) contextualisation in defence reform in the DRC see Baaz and Stern (2017). 
(Rublee 2008: 429f.): first, uncertainty about a task or the outcome of a social process, which makes actors more likely to accept outside influence; second, the similarity to the norm transmitter, which also contributes to a higher acceptance of outside influence; and third, intergroup conflict of the affected society, which diminishes efforts of co-operation and influence on norms. There is, perhaps, a further dynamic at play worth commenting on; those norms being transmitted or imposed are not internalised by norm transmitters. This leads to issues of credibility and legitimacy, with the potency of norm transmission being influenced by the extent to which the gap between policy and practice is evident or can be exploited by those in the affected society.

While patterns of "localisation" by "norm entrepreneurs" or "norm-takers" can also be found in the post-conflict context, it is particularly the contested aspect of norm diffusion that is understudied. On the one hand, we can expect that international norms on SSR are adapted in those cases where national government or local, non-state actors such as local self-defence groups see them align with their own cultural belief systems or beneficial to their own objectives - one example being the local chiefs in Sierra Leone mentioned above, who saw the decentralisation reforms quite fitting for a retention of local power dynamics (according to Nickson and Cutting 2016; it is worth noting that other scholars view the impact of decentralisation upon the power of chiefs less positively - cf. Albrecht 2010). And in times of high uncertainty, after armed conflict has ended and post-conflict order will be re-established, we might assume a higher acceptance of outside actors to the field, as suggested by Rublee $(2008,430)$. Given the enormity of the task of reconstructing or reforming the security and justice sector in some cases, and given the concept of SSR may be new to some, it can be further anticipated that SSR norms may be accepted by national governments or local actors, and others may be rejected.

However, this does not appear to be the case in practice very often. This can be, in part, explained by the thesis that SSR norms are less likely to be appropriated when they conflict with or are dissimilar to local norms (Rublee 2008, 430). This is of particular importance for influence of international donors and SSR actors such as UN and World Bank, who have very different normative legacies and follow a very different norm system from the post-conflict countries they are active in. Furthermore, drawing from Rublee's theoretical assumptions, where post-conflict environments are often characterised by internal divisions, it can be expected that external efforts to influence norms will be unsuccessful (Rublee 2008, 429f.). Indeed, in the immediate aftermath of conflict, where power is shifting and local actors are vying for control, it can be expected that local actors will be less likely to accept external norms, especially those that may limit the power of elites, as SSR norms generally do. On the other hand, in such a context, local actors may express amenability to external norms as a means of generating partnerships with influential external actors that can gain them political leverage and even help consolidate their power. Thereafter, norm adoption may be a slow process of negotiation, adaption and/or resistance by a myriad of different local actors engaged in or influential over SSR, its planning, its implementation and its outcomes.

The articles in this special issue shed light on these aspects of norm imposition, adoption, adaption, and contestation. They discuss aspects of diverging historical legacies that have an impact on the contestation of internationally promoted SSR norms (Author A); the adaption of international models on community-policing for political purposes (Author B); and the interaction between different normative areas of SSR and the judiciary (Author C). 
Author A's article traces the legacies and variances of "community-based policing" in Timor-Leste and analyses in detail its historical roots and cross-cultural socio-political influences. In particular, the article explores the historical reasons for a failure of the community-based policing approach promoted by the United Nations Transitional Administration (UNTAET). Drawing on diffusion theory, Author A shows that policing in Timor-Leste evolved by way of a transfer of historical norms of policing from Japan to Indonesia and, with the Indonesian occupation, onwards to Timor-Leste. However, when the UN tried to implement their normative blueprint of community policing in Timor-Leste, they did not take into account prevailing modes of policing. This eventually led to a normative conflict in respect of diverging ideas about policing, which was discharged in the violent encounters between citizen, police, and military. Author A's article shows the importance of international peace missions engaged in SSR attending to existing norms on the ground - and for research to take historical dynamics and processes into account when explaining contemporary challenges in the thematic field of security governance. The article thus makes an important contribution to existing literature about more holistic perspectives of security governance that take into account influences from various backgrounds.

Community policing is also the topic of Author B's article. Through an ethnographic lens, the article analyses the effects of Ugandan local community policing initiatives on the country's security architecture. Because the Ugandan police has long been instrumentalised by its authoritarian regimes, community policing was seen - in the specific Ugandan context - as pathbreaking and novel by external donors such as the UK to bring the police closer to the people. In his research, Author B found that while community policing is somewhat appreciated and used by citizens, the scheme operates in a legal ambiguity: it has sometimes led to civilians taking over police duties, and has been routinely politicised in regime security strategies. Community policing might thus be acclaimed by development partners as best practice to closer connect police to the local communities. Yet, with little regard for the actual context, it might result in normative conflicts, further entrenching elite power and removing the provision of security from those most in need. Using a framework of political policing, Author B shows that, while publicly serving the idea of democratically-driven police work, community policing is in fact a tool of the regime for its own survival. This is in particularly the case during times of potential political instability, such as around elections. Similar to Author A's observations, Author B's research shows that a norm that is brought to a country from abroad might turn out very different in everyday life, depending on the level of adaption and change by local actors.

The interaction between the security context and the normative assumptions of SSR is also pointed out by Author C. Drawing on the assumptions of historical institutionalism, Author C shows that the tendency to overlook justice system reform in the context of SSR and wider peacebuilding efforts has serious consequences for the quality and sustainability of peace. The case study of El Salvador highlights that even though the country is often praised as a showcase of liberal peacebuilding, peace should mean more than the absence of war. The persistent high levels of violence in El Salvador are closely linked to a lack of comprehensive reforms in the justice system. In particular, the political elites of the country, with their sweeping Amnesty Law that was not included in the peace agreement of 1992, paved the way for impunity for the major human rights violations that were committed throughout the 1980-1992 civil war. Necessary reforms in the 
security and justice sectors were undermined by social coalitions between political elites in El Salvador; Author C's article underscores the impact that powerful elite groups can have on reform efforts. The effects of limited justice sector reform, however, persist, with continued impunity for human rights violations. As Author C's research highlights, the immediate aftermath of armed conflict provides an opportunity to institute reforms; if efforts to reform the justice sector and inculcate a culture of accountability do not begin swiftly, it can be very difficult later on to dismantle a culture of impunity.

With case studies from different parts of the world, the articles demonstrate that, due to specific context and idiosyncrasies, there is no international normative assumption on SSR that might ever be implemented as envisaged by international donors. In all cases, internationally accepted norms of SSR have been imposed, contested, adapted and changed according to the local specificities and needs. With any attempt of norm diffusion, it is thus important to adopt a more holistic approach and account for historical, cultural and socio-political legacies, which are decisive for the outcome of norm appropriation. The contributions also stress the importance to focus on those who produce and experience security on a local level as the actual agents of SSR and actors of the related norm diffusion - which ties in with the anti-colonial readings of critical peacebuilding and statebuilding literature mentioned above (cf. Sabaratnam 2017: 19ff.).

As is already evident, the role of local actors at the state and sub-state level in conflict-affected environments, and their relationship with external or international actors is, of course, critical, in the process of norm appropriation. The next section will take a closer look at the relationship between these various actors and how co-operation and contestation can impact the implementation of SSR programmes and the extent to which their intended objectives are achieved.

\section{A myriad of actors}

As outlined above, internationally-led SSR programmes continue to be informed by Weberian notions of the state, which is very much a Western construct, in which the state claims a monopoly of the legitimate use of force, and thus tend to be focused upon the (re-)establishment of organized and legitimate state force as an answer to conflict-torn societies (Mannitz 2014). While the principle of local ownership and context specificity are enshrined in policy (OECD 2005, 2007; UN 2014), the "classical Weberian model of statehood" (Schroeder and Chappuis 2014: 134) still prevails and frequently fails to see the reality that is so evident in many post-conflict states: particularly in African, Asian, and Latin American states, state security institutions are only one of a plurality of actors that provide security and justice to its citizens (Baker 2010; Jackson 2018; Jackson and Bakrania 2018; Sedra 2018). In many countries, the vast majority of the population accesses security and justice through informal or non-state providers, or customary or traditional security and justice systems, with $80 \%$ to $90 \%$ of people in the Global South accessing security or justice through informal providers according to some estimates (Albrecht and Kyed 2011; Baker 2010). This is particularly the case in conflict-affected and developing countries (see Baker 2010; Baker and Scheye 2007) and particularly where state institutions lack capacity or credibility, or access to them is problematic. The urban poor and people in rural areas are particularly likely to access informal security and justice mechanisms; again, generally reflective of the fact that state 
institutions do not or cannot adequately respond to the needs of the people, particularly those at the margins of society.

However, while there are some examples of inclusion of non-state providers into security models, as mentioned above, many internationally-funded SSR programmes continue to focus on building the effectiveness of state institutions, often neglecting non-state security actors like traditional justice and security mechanisms or self-defence groups. Critical research now widely acknowledges that state-centric SSR approaches fail to take into account the diversity of formal and informal security actors that exist in places where programmes are implemented (Baker 2010; Donais 2017; Gordon 2014). It is important to note that efforts to engage non-state providers into security models and non-state actors into reform programmes are limited for many reasons. Aside from the fact that there may be concern about capacity, knowledge, legitimacy and adherence to international standards or norms - or at least likely acceptance of intended outputs of external donors and other actors (Sedra 2010), engaging non-state actors requires more resources, due to the increased number and type of actors and resultant complexity (Gordon 2014). Additionally, such efforts can take longer to deliver outputs, particularly where there are many different actors and approaches to providing security. This is problematic where donors need to demonstrate results in short timeframes (Oosterveld \& Galand, 2012) and the security risks prevalent in environments in the immediate aftermath of conflict require urgent attention (StabilisationUnit, 2014). With increased number and type of actors, consensus on the way forward can be hard to reach and can, thus, potentially compromise efforts. The costs and risks associated with engaging non-state providers into security models and non-state actors into reform programmes, therefore, tend to result in limiting the scope of actors engaged in and addressed by reform programmes. Of course, it is not only international actors engaged in SSR programmes who have a vested interest in limiting the scope of actors engaged in or addressed within reform programmes. State actors within conflict-affected societies may also be inclined to limit the number of actors engaged in SSR for fear of relinquishing power, given SSR is fundamentally about renegotiating and redistributing power and can significantly limit the power of elites (Heupel, 2012); engaging nonstate actors, those who have the most to gain from a redistribution of power, may therefore be resisted. Non-state actors might also have no interest in engaging in externally-driven reform programmes, particularly if they distrust external actors (Narten, 2008). These explanations tend to assume, however, that effective and responsive security and justice sector institutions, which enjoy broad-based public confidence and trust, can be built without engaging a broad cross-section of those whom such institutions are meant to serve and without acknowledging how they currently access justice and security.

Policy discourse acknowledges the need to incorporate perspectives from the Global South (e.g. UN 2014), yet it often falls short on describing how in detail this can be done in a volatile and dynamic post-conflict environment. Even in SSR scholarship, there is significant literature which argues for incorporating non-state actors (both within and beyond the security sector) in SSR programmes (Baker 2010; Derks 2012; Gordon 2014; Jackson 2011; Jackson 2010; Price and Warren 2017), while very little describes ways in which this can be successfully done beyond identifying the opportunities and challenges that exist. Outside academic literature, the work of the Geneva Centre for the Democratic Control of Armed Forces (DCAF) and the Centre for Security Governance (CSG) in Ontario are particularly notable exceptions. 
In practice, informal or traditional security and justice mechanisms continue to be overlooked. Burian (2017) notes, for instance, that while there is significant investment in SSR across Mali, Nigeria, Liberia and Guinea Bissau, there is only one example across all of these countries of a programme working with non-state actors. This is often because of security, logistical, financial, political and epistemological concerns. There may be security and logistical challenges which problematize access. It is also often easier for international actors engaged in SSR programmes to engage state representatives who are more familiar, more reachable and who may also share similar views or speak the same language (Sedra 2010; Mobekk 2010). There may be a level of fear, or suspicion of informal security and justice providers, or disregard of any expertise or legitimacy they are considered to have (Donais 2009). International actors also often assume that it is quicker and cheaper to engage with actors and institutions at the state-level, rather than extend the type and number of co-ordination mechanisms with a plethora of other actors across the country or region. It may be perceived as harder to control outcomes if the number of actors engaged expands, particularly if those actors do not share similar views, cultures or experience. Where outcomes need to be predictable and swift or may otherwise potentially compromise peacebuilding, engagement with those beyond the state-level may be limited. Of course, many of these challenges exist. Informal security and justice mechanisms can also be unaccountable, corrupt and discriminatory, particularly against women and marginalised groups, reinforcing social structures and exclusion and perpetuating human rights violations (Jackson 2010, 2011). The same is, of course, true for state institutions (see Denney and Domingo 2013). Without romanticising the local (Mac Ginty 2015; Richmond 2011), informal security and justice mechanisms can be more responsive to the needs of people, cheaper, quicker, fairer, more understandable and, as such, can contribute significantly to providing access to justice, particularly to the poorer and more vulnerable members of society. Ignoring informal security and justice mechanisms, therefore, undermines prospects for building security and justice and, consequently, prospects for long-term peace.

This is not to argue that informal security and justice providers should necessarily be formally incorporated into SSR programmes, as this can compromise their value, legitimacy and the public trust and confidence they might enjoy. But their role in providing security and justice needs to be acknowledged, and not undermined by building or strengthening processes, policies and institutions that may harm their effectiveness (Gordon 2014) or turn them into "spoilers" (Meharg and Arnusch 2010).

Besides the multitude of actors, including non-state actors, in the post-conflict country itself, there might also be multiple international donors. Often it is assumed that they follow the same statecentric norms and have the same goals. However, their aims, in particular in regards to peace, justice or security, may well differ - and their approaches to SSR are often informed by what works in their own country or what may be a favourable outcome for their own geopolitical strategies. Thus, tension can arise during SSR planning and can result in challenges during and after implementation, particularly if different countries have led on reforming different aspects of the security sector. In Afghanistan, for instance, following the 2011 Bonn Agreement, the US led on defence reform, Germany on police reform, Italy on judicial reform, UK on counter-narcotics, and Japan on DDR before NATO assumed responsibility for training Afghan National Security 
Forces (ANSF) (DCAF 2015a). This posed challenges for co-ordination and, ultimately, implementation given the different sectors within the broader security sector are interdependent and changes in one inevitably affect another (DCAF 2015b). In Kosovo, before the Unilateral Declaration of Independence, the many countries involved in preliminary discussions regarding future security structures advocated different structures based upon their own experience as well as their geopolitical interests. This resulted in prolonged discussions on the merits of different types of security sector institutions (such as a gendarmerie, security force, civilian-led quasiDefence Ministry) and tension between the various international actors, rather than a focus on security needs (which would determine the type of structures and capacity required) and relations with local actors (author's engagement in the UN in Kosovo 2004-2008). As Knight's (2010) research on linkages between SSR and DDR in post-conflict African countries, suspicion between national actor and poor co-ordination between external actors can compromise success, as a result of non-compliance or delays in implementation, gaps or duplication of effort and subsequent deficiencies and confusion, wasted resources, and competition between actors rather than focus on shared goals. Likewise, Lamb and Stainer (2018) underscore the importance of co-ordination between various stakeholders engaged in DDR, drawing from the example of South Sudan, to avoid misunderstandings, inter-organisational tensions, rivalries and mistrust between stakeholders and the subsequent impact these can have on implementation and outcomes. As DDR and SSR incorporate increasing numbers and type of actors - including civil society actors, private sector companies, regional organisations - co-ordination efforts are further problematized (Lamb and Stainer 2018; Paris 2009).

Articles in this special issue address ways in which different actors or stakeholders engaged in SSR and DDR may compete or co-operate, and how their normative assumptions may collide and, consequently, further complicate planning and implementation of programmes. The contributions pay particular attention to the relationship between state and non-state actors: assumptions about who has the necessary skills, knowledge and aptitude to work in the security sector or engage in SSR, which tends to marginalise those not perceived to be part of the formal security sector as well as privilege those considered to be representative or constitutive of the state (Author D); the integration of combatants from non-state armed groups after conflict into state armed forces (Author E, Author D); the impact certain non-state (and state) actors can have on undermining prospects for programmatic success (Authors F); as well as the role of local communities in community policing schemes (Author B, Author A).

Author D's article reflects upon the continued marginalisation of women in SSR, particularly defence reform, despite the fact that gender-responsive SSR is increasingly recognised as being key to success. Author D investigates reasons for women's marginalization, focussing particularly on attitudes towards women in the defence sector and assumptions about a woman's place and her skillsets, aptitude and interests. By analysing developments in Nepal, Sri Lanka, Kosovo and Colombia, Author D explores the paradox of women's marginalisation in defence reform and post-reform defence structures, in places where women were active combatants in large numbers during the preceding conflict. Author D adopts a feminist institutionalist approach to show how SSR helps security sector institutions construct and reconstruct gender power relations, reinforce gendered dynamics of exclusion, and determine gendered outcomes. Author D argues that genderresponsive defence reform that moves beyond simply adding women has the potential to influence 
gendered assumptions women's and men's place and skillsets, and thereby alter gender power relations within and beyond the defence sector, and, with it, enhance the security of women and build more sustainable peace.

Author E's article also looks at DDR and defence reform, specifically the integration of former combatants from insurgent or non-state armed groups into state armed forces after conflict. While Author D's article helps to fill a gap in the literature on the gender dynamics of SSR, DDR and the links between the two, Author E's article contributes to addressing the gap in the literature on the modalities of military integration as part of DDR processes. Author E discusses how military power sharing through the integration of both or several conflict parties in post-conflict security sector institutions can respond to the challenge of demobilising combatants from non-state armed groups who may not want to relinquish their status or control or who may lack confidence or trust in the government and its security forces. Drawing on assumptions from bargaining literature and empirical analysis of 77 post-conflict countries between 1989 and 2013, Author E argues that military integration of rebel fighters in the national armed forces can be a strong signal of the conflict parties' commitment to the peace process and can contribute to building a stable peace. Author $\mathrm{E}$ also shows that civil war is more likely to recur if forces of former warring parties such as rebel groups are retained during the military integration process. This is, perhaps, unsurprising, given maintenance of rebel forces is a clear indication of lack of faith in the peacebuilding process, and a strong signal that there are other factors which undermine prospects for long-term peace. This also would seem to reaffirm the importance in peacebuilding of the state being able to claim a monopoly of the legitimate use of force. Additionally, Author E's analysis shows that civil war is more likely to recur if the military plays an important role in the post-conflict economy, including a larger proportion of the labour market comprising the military.

Authors F's article also considers how the presence of certain actors can undermine prospects for successful peacebuilding. Specifically, they consider the role of so-called veto players - a term drawn from game theory, meaning actors who have sufficient power to stop a proposed or planned action - and their impact on DDR programmes. In so doing they contribute to the literature on DDR by investigating the precise factors that lead to successful DDR. By looking at Nepal and the Democratic Republic of Congo (DRC), Authors F show that the likelihood of successfully implementing post-conflict DDR programmes decreases as the number of veto players increases. So, in Nepal, the small number of veto players helped the implementation of DDR, although other factors of course compromised full success (not least that former combatants left cantonments only in 2012 when the civil war had ended 6 years previously - see Bhandari 2015). In contrast, whereas the high number of veto players from within and outside DRC posed a particular challenge to the implementation of the DDR program, ultimately leading to difficulties in integrating all players and demobilising the high number of diverse groups.

Authors $\mathrm{F}$ also argue that the policy distance between veto players and lack of internal cohesion of veto players does not negatively impact DDR implementation. This is a significant finding which runs counter to intuitive assumptions about ethnic cleavages and fractionalization as being critical risk factors in DDR programmes. Authors F's highlight the deficits in veto player theory when applied to the dynamic and challenging context of post-conflict environments, but their findings are an important contribution to the literature on DDR. 
Other articles in this special issue demonstrate how the specific actors, and the multiplicity of actors, can problematize SSR programmes. For example, the article by Author A points to the difficulties of co-operation between several international and local actors. Although on paper the UN Transitional Administration in Timor-Leste had all the necessary resources to create lasting peace, in practice the different assumptions about policing between the UN, other bilateral donors, and local police forces culminated in a lack of implementation of the ambitious plans and eventually led to renewed violence against civilians and the army. In a similar vein, Author B finds that the British Police Training Team (BPTT) that introduced community policing in Uganda in 1989 did not intend it to become a major tool of the regime for its own survival, but rather saw it as way to induce democratic norms and values. Of course, community policing programmes - as with all peacebuilding interventions - cannot be developed and implemented without consideration of the context if the aims of such programmes are to be met. There is a need to consider how such programmes might be received by the various actors on the ground as well as how such programmes might interact with the socio-political dynamics, historical and cultural specificities, and other peacebuilding activities already underway or planned. As the articles by Authors A and B highlight, if there is little regard for the historical (Author A) or political context (Author B) and the ways in which new programmes and concepts might be accepted, adapted or "mis-used" by various actors, such programmes are unlikely to meet intended objectives and be successful.

\section{The Complexity and Political Dimensions of Security Sector Reform}

The articles in this in this special issue contribute to understanding the complex and political dimensions of SSR. The articles build upon previous research on SSR by investigating patterns that lead to a variation of norm adoption, contestation and imposition, which have a major impact on building long-term and inclusive peace. They also tackle questions of contestation and cooperation between a multitude of different actors beyond the level of the state. The articles taken together show how both the multiplicity of and tension between norms and actors further complicates efforts to build peace. While opportunities exist with the presence of actors beyond the level of the state and normative frameworks beyond the vision of the donors from the Global North, the problems arising from contestation, confusion and tension cause delays, waste resources and threaten to derail the peace process.

The politicised nature of DDR and SSR, concerning the redistribution of power within society, namely through the security sector, adds to the complexity and risk. Drawing from the insights of the articles in this collection, and from the application of complexity theory to peacebuilding (de Coning 2018), we can see how proliferation of and contestation between actors, and between their normative positions, may be less likely to lead to SSR and DDR programmes being effectively implemented and intended outcomes being achieved. The post-conflict environment is already complex, dynamic and non-linear; it is not an empty canvas, singular moment, or static frame with which to impose, inform or interact. The aim of any peacebuilding intervention is to influence this complex, dynamic and non-linear social system that is the conflict-affected environment (de Coning 2018). An awareness of this complexity of context and process is required if SSR, DDR and other peacebuilding interventions are to be successful and create a meaningful peace for all in 
society. As part of this awareness, there is a need to attend to the multiplicity of actors and how they might interact and influence, as well as how norms are adopted, contested and imposed. This is necessary as it is contended that these aspects are critical to how security and justice sector institutions are built, reformed or developed; how they are subsequently regarded, accepted, or rejected by those the institutions ostensibly serve; and ultimately the extent to which they contribute to rebuilding security and justice after conflict and paving the way to sustainable, meaningful and comprehensive peace.

Ultimately, the complexity and political nature of SSR need to be acknowledged if SSR programmes are to be successful. Fundamentally, there is a need to genuinely acknowledge that programmes need to respond to the specificity of the context; its socio-political dynamics, historical and cultural specificities, and the myriad of actors and activities already present. Further, the different actors engaged to a greater or lesser extent in determining the parameters, engaging in, or subject to SSR and related DDR programmes need to be acknowledged. What also needs to be recognised is that the extent of these actors' engagement in SSR and DDR tends to reflect and, in turn, reinforces their position in society. Hence, women tend to be marginalised and non-state security and justice providers tend to be overlooked. The status of actors also impacts outcomes, and so a high number of veto players can compromise DDR efforts and a military force which dominates an economy can undermine the prospects of long-term peace. In short, these articles demonstrate that what is required is an awareness of these complexities, building on the opportunities and challenges presented in each specific context, and cognisant of power and its manifestations and effects.

\section{References}

Acharya, Amitav. 2004. "How Ideas Spread: Whose Norms Matter? Norm Localization and Institutional Change in Asian Regionalism." International Organization 58 (2): 239-275.

Africa, Sandy. 2008. "South Africa: SSR after Apartheid." In Local Ownership and Security Sector Reform, edited by Timothy Donais, 169-189. Geneva: LIT Verlag/DCAF.

African Union Commission. 2014. African Union Policy Framework on Security Sector Reform. Addis Ababa, Ethiopia: African Union. http://www.peaceau.org/uploads/au-policy-framework-on-securitysector-reform-ae-ssr.pdf.

Albrecht, Peter, and Paul Jackson. 2014a. Securing Sierra Leone 1997 - 2013: Defence, Diplomacy and Development in Action. Whitehall Paper 82. Abingdon: Routledge Journals.

Albrecht, Peter, and Paul Jackson. 2014b. "State-Building through Security Sector Reform: The UK Intervention in Sierra Leone.” Peacebuilding 2 (1): 83-99. doi:10.1080/21647259.2013.866460.

Albrecht, Peter and Helene Maria Kyed 2011. "Introduction: Non-state and Customary Actors in Development Programs." In Perspectives on Involving Non-State and Customary Actors in Justice and Security Reform, edited by P. Albrecht, H. M. Kyed, D. Isser and E. Harper, p3-21. International Development Law Organization (IDLO) and The Danish Institute for International Studies (DIIS). http://pure.diis.dk/ws/files/61420/DIIS_Book.pdf.

Albrecht, P.; Stepputat, F.; Andersen, L. 2010. "Security Sector Reform, the European Way.” In The Future of Security Sector Reform, edited by Mark Sedra, 74-87. Waterloo: CIGI

Andersen, Louis Riis. 2011. "Security Sector Reform and the Dilemmas of Liberal Peacebuilding." DIIS Working Paper, Copenhagen: Danish Institute of International Studies.

Andersen, Louis Riis. 2012. "The Liberal Dilemmas of a People-Centred Approach to State-Building." Conflict, Security \& Development 12 (2): 103-121. doi:10.1080/14678802.2012.688288

Ansorg, Nadine. 2017. "Security sector reform in Africa: Donor approaches versus local needs". Contemporary Security Policy 38(1): 129-144. 
Ansorg, Nadine, and Toni Haastrup. 2018. "Gender and the EU's Support for Security Sector Reform in Fragile Contexts: Gender \& the EU's Support to SSR.” JCMS: Journal of Common Market Studies, March. doi:10.1111/jcms.12716.

Ansorg, Nadine, and Sabine Kurtenbach. 2017. "Introduction: Institutional Reforms and Peace Building." In Institutional Reforms and Peacebuilding. Change, Path-Dependency and Societal Divisions in Post-War Communities, edited by Nadine Ansorg and Sabine Kurtenbach, 1-18. Conflict, Development and Peacebuilding. Abingdon, Oxon: Routledge.

Ayub, Fatima, Sari Kouvo, and Rachel Wareham. 2009. Security Sector Reform in Afghanistan. Country case study: Afghanistan. IFP Security Cluster. London: Initiative for Peacebuilding.

Baker, Bruce. 2010. “The Future Is Non-State.” In The Future of Security Sector Reform, edited by Mark Sedra, 208-228. Ontario: Centre for International Governance Innovation [CIGI]. http://www.cigionline.org/sites/default/files/The $\% 20$ Future $\% 20$ of $\% 20$ Security $\% 20$ Sector $\% 20$ Reform.pdf.

Baker, Bruce, and Eric Scheye. 2007. "Multi-Layered Justice and Security Delivery in Post-Conflict and Fragile States: Analysis." Conflict, Security \& Development 7 (4): 503-528. doi:10.1080/14678800701692944.

Baaz, Maria Eriksson, and Maria Stern. 2017. "Being Reformed: Subjectification and Security Sector Reform in the Congolese Armed Forces." Journal of Intervention and Statebuilding 11 (2): 207-224. doi:10.1080/17502977.2017.1337338.

Benedix, D., and R. Stanley. 2008. "Deconstructing Local Ownership of Security Sector Reform: A Review of the Literature." African Security Review 17 (2): 93-104. doi:10.1080/10246029.2008.9627475.

Bhandari, Chiranjibi. 2015. "The Reintegration of Maoist Ex-Combatants in Nepal." Economic and Political Weekly 50(9): 28 February. https://www.epw.in/journal/2015/9/conflict-transition-anddevelopment-special-issues/reintegration-maoist-ex-combatants.

Brusset, Emery, Cedric de Coning and Bryn Hughes. 2016. Complexity thinking for peacebuilding practice and evaluation. Basingstoke: Palgrave Macmillan.

Burian, Alexander. 2017. "Summary of Key SSR Developments and Trends 2005-2017." ISS AT Blog. https://issat.dcaf.ch/Share/Blogs/ISSAT-Blog/Summary-of-Key-SSR-Developments-andTrends-2005-2017.

Call, Charles. 2007. Constructing Justice and Security After War. Washington DC: USIP.

Chanaa, Jane. 2002. Security Sector Reform: Issues, Challenges and Prospects. Adelphi Paper, no. 344. Oxford ; New York: Oxford University Press for the International Institute for Strategic Studies.

Chandler, David, 2000. Bosnia: Faking Democracy after Dayton. Pluto Press, London.

Chandler, David. 2006. "State-Building in Bosnia: The Limits of 'Informal Trusteeship." International Journal of Peace Studies 11 (1): 17-38.

Checkel, Jeffrey T. 1999. "Norms, Institutions, and National Identity in Contemporary Europe." International Studies Quarterly 43 (1): 84-114. doi:10.1111/0020-8833.00112.

Cheng, Christine, Jonathan Goodhand, and Patrick Meehan. 2018. Elite Bargains and Political Deals Project. Synthesis Paper: Securing and Sustaining Elite Bargains that Reduce Violent Conflict. Stabilisation Unit.

Commission, E. 2016. JOINT COMMUNICATION TO THE EUROPEAN PARLIAMENT AND THE COUNCIL, Elements for an EU-wide strategic framework to support security sector reform. Von EC: https://ec.europa.eu/europeaid/sites/devco/files/joint-communication-ssr20160705-p1-854572_en.pdf

de Coning, Cedric. 2018. "Adaptive peacebuilding." International Affairs 94 (2): $301-$ 317, https://doi.org/10.1093/ia/iix251.

Denney, Lisa and Domingo, Pilar. 2013. "A problem-focussed approach to violence against women: the political-economy of justice and security programming." London: Overseas Development Institute (ODI). https://www.odi.org/sites/odi.org.uk/files/odi-assets/publications-opinionfiles/8325.pdf.

Denney, Lisa, and Craig Valters. 2015. Evidence Synthesis: Security Sector Reform and Organisational Capacity Building. London: Department for International Development (DFID).

Derks, Maria. 2012. Improving Security and Justice through Local/Non-State Actors. The Challenges of Donor Support to Local/Non-State Security and Justice Providers. Netherlands Institute of International Relations 'Clingendael.'

https://www.clingendael.org/sites/default/files/pdfs/20120400_derks_improving_security.pdf. 
Donais, T. 2009. "Inclusion or Exclusion? Local Ownership and Security Sector Reform.” Studies in Social Justice 3 (1): 117-131.

Donais, T. 2017. "Engaging Non-State Security Providers: Whither the Rule of Law?" Stability: International Journal of Security \& Development 6 (1): 1-13, doi: https:/ / doi.org/10.5334/sta.553.

Donais, Timothy. 2018. "Security Sector Reform and the Challenge of Vertical Integration." Journal of Intervention and Statebuilding 12 (1): 31-47. doi:10.1080/17502977.2018.1426681.

Donais, T., and A. Knorr. 2013. "Peacebuilding from Below vs. the Liberal Peace: The Case of Haiti." Canadian Journal of Development Studies / Revue canadienne d'études du développement 34 (1): 54-69. doi:10.1080/02255189.2013.761130.

Duffield, M. 2007. Development, Security and Unending War: Governing the World of Peoples. Cambridge: Polity.

Duncanson, Claire. 2016. Gender and Peacebuilding. Cambridge: Polity Press.

Ebo, Adedeji. 2007. Towards a Common ECOW AS Agenda on Security Sector Reform. Geneva: Geneva Centre for the Democratic Control of Armed Forces (DCAF).

Geneva Centre for the Democratic Control of Armed Forces (DCAF). 2015a. "Afghanistan SSR Snapshot”, SSR Country Snapshot. Geneva: DCAF. https://issat.dcaf.ch/Learn/ResourceLibrary/Country-Profiles/Afghanistan-SSR-Snapshot.

Geneva Centre for the Democratic Control of Armed Forces (DCAF). 2015b. "The Security Sector: Roles and responsibilities in security provision, management and oversight." SSR Backgrounder. Geneva: DCAF. http://ssrbackgrounders.org/fall.php?p=18\&l=EN.

Geneva Centre for the Democratic Control of Armed Forces (DCAF). 2017. "Somalia SSR Background Note.” Geneva: DCAF. https:/ /issat.dcaf.ch/Learn/Resource-Library/CountryProfiles/Somalia-SSR-Background-Note.

Geneva Centre for the Democratic Control of Armed Forces (DCAF). 2018. "Triangulation Rapport Between State, Donor and Civil Society in Indonesia." Geneva: DCAF. https://issat.dcaf.ch/Learn/Resource-Library2/Case-Studies/Triangulation-Rapport-BetweenState-Donor-and-Civil-Society-in-Indonesia.

Germann, Wilhelm N. 2002. "Evaluation of Security Sector Reform and Criteria of Success: Practical Needs and Methodological Problems." Working Paper No. 85. Geneva: DCAF. http://www.iskran.ru/cd_data/disk2/rr/016.pdf.

Gordon, Eleanor. 2014. "Security Sector Reform, Statebuilding and Local Ownership: Securing the State or Its People?" Journal of Intervention and Statebuilding 8 (2-3): 126-148. doi:10.1080/17502977.2014.930219.

Grady, Kate. 2010. "Sexual Exploitation and Abuse by UN Peacekeepers: A Threat to Impartiality" International Peacekeeping 17(2): 215-228.

Heathershaw, John. 2008. "Unpacking the Liberal Peace: The Dividing and Merging of Peacebuilding Discourses.” Millennium - Journal of International Studies 36 (3): 597-621. doi:10.1177/03058298080360031101.

Heupel, Monika. 2012. "Rule of Law Promotion and Security Sector Reform: Common Principles, Common Challenges." Hague Journal on the Rule of Law 4 (1): 158-175.

Holohan, Anne. 2016. "Peacebuilding and SSR in Kosovo: An Interactionist Perspective." Global Crime 17 (3-4): 331-351. doi:10.1080/17440572.2016.1197508.

Jackson, Paul. 2010. "SSR and Post-Conflict Reconstruction: The Armed Wing of State Building?” In The Future of Security Sector Reform, edited by Mark Sedra, 118-135. Waterloo, Ont.: Centre for International Governance Innovation [CIGI]. http://www.deslibris.ca/ID/225839.

Jackson, Paul. 2011. "Security Sector Reform and State Building." Third World Quarterly 32 (10): 18031822. doi:10.1080/01436597.2011.610577.

Jackson, Paul. 2018. "Introduction: Second-Generation Security Sector Reform." Journal of Intervention and Statebuilding 12(1): 1-10. doi: 10.1080/17502977.2018.1426384.

Jackson, Paul and Shivit Bakrania. 2018. "Is the Future of SSR non-linear?" Journal of Intervention and Statebuilding 12(1):11-30. doi: 10.1080/17502977.2018.1426548.

Klopfer, Franziska, Douglas Cantwell, Miroslav Hadžić, and Sonja Stojanović. 2012. Almanac on Security Sector Oversight in the Western Balkans: 2012. Belgrade; Geneve: Centre for Security Policy ; Centre for the Democratic Control of Armed Forces.

Knight, M. 2009. "Security Sector Reform, Democracy and the Social Contract: From Implicit to Explicit." Journal of Security Sector Management 7 (1): 1-20. 
http://www.ssronline.org/jofssm/issues/jofssm_0701_knight.pdf?CFID=4098420\&CFTOKE $\mathrm{N}=57140008$.

Knight, W. Andy. 2010. "Linking DDR and SSR in Post Conflict Peace-building in Africa: An Overview." African Journal of Political Science and International Relations, 4(1): 29-54.

Lamb, Guy and Stainer, Theo 2018. "The Conundrum of DDR Coordination: The Case of South Sudan." Stability: International Journal of Security and Development 7(1): 1-9. doi: http://doi.org/10.5334/sta.628.

Laliberté, Nicole. 2016. 'Peace begins at home': Geographic imaginaries of violence and peacebuilding in northern Uganda" Political Geography 52: 24-33.

Lammy Review. 2017. The Lammy Review. An Independent Review into the Treatment of, and Outcomes for, Black, Asian and Minority Ethnic Individuals in the Criminal Justice System. London: Government of the United Kingdom.

https:// assets.publishing.service.gov.uk/government/uploads/system/uploads/attachment_data / file/643001/lammy-review-final-report.pdf.

Lemay-Hébert, Nicolas. 2013. "Everyday Legitimacy and International Administration: Global Governance and Local Legitimacy in Kosovo." Journal of Intervention and Statebuilding 7 (1): 87-104. doi:10.1080/17502977.2012.655622.

Mac Ginty, Roger. 2010. "Hybrid Peace: The Interaction Between Top-Down and Bottom-Up Peace." Security Dialogue 41 (4): 391-412. doi:10.1177/0967010610374312.

Mac Ginty, Roger. 2015. "Where is the local? Critical localism and peacebuilding." Third World Quarterly 36(5): 840-856, doi: 10.1080/01436597.2015.1045482.

Malan, M. (2008). Security Sector Reform in Liberia: Mixed Results from Humble Beginnings. Von Strategic Studies Institute, U.S. Army War College: https://www.globalsecurity.org/military/library/report/2008/ssi_malan.pdf

Mannitz, Sabine. 2014. "From Paternalism to Facilitation: SSR Shortcomings and the Potential of Social Anthropological Perspectives." International Peacekeeping 21 (2): 269-285. doi:10.1080/13533312.2014.910403.

Marijan, Branka. 2017. The Gradual Emergence of Second Generation Security Sector Reform in Bosnia-Herzegovina. Ontario: Centre for Security Governance (CSG).

McFate, Sean. 2010. The Link Between DDR and SSR in Conflict-Affected Countries. United States Institute of Peace. https://www.usip.org/publications/2010/05/link-between-ddr-and-ssr-conflict-affectedcountries.

Meharg, Sarah Jane, and Aleisha Arnusch. 2010. Security Sector Reform: A Case Study Approach to Transition and Capacity Building. Edited by Susan Merrill. PKSOI Papers. Carlisle, PA: Strategic Studies Institute, U.S. Army War College.

Mobekk, Eireen. 2009. Security Sector Reform and the UN Mission in the Democratic Republic of Congo: Protecting Civilians in the East. International Peacekeeping, 16(2), 273-286.

Mobekk, Eiren. 2010. "Security Sector Reform and the Challenges of Ownership." In The Future of Security Sector Reform, edited by Mark Sedra, 230-243. Ontario: CIGI.

Narten, J. 2008. Post-Conflict Peacebuilding and Local Ownership: Dynamics of External-Local Interaction in Kosovo under United Nations Administration. Journal of Intervention and Statebuilding, 2(3), 369-390.

Nickson, Andrew, and Joel Cutting. 2016. "The Role of Decentralisation in Post-Conflict Reconstruction in Sierra Leone." Third World Thematics: A TWQ Journal 1 (6): 799-816. doi:10.1080/23802014.2016.1353890.

OECD. 2005. Security System Reform and Governance a DAC Reference Document. Paris: Organisation for Economic Co-operation and Development. http://accesbib.uqam.ca/cgibin/bduqam/transit.pl?\&noMan=24128332.

OECD. 2007. OECD DAC Handbook on Security System Reform. Supporting Security and Justice. Paris: OECD.

OHCHR. 2017. Statement to the Media by the United Nations' Working Group of Experts on People of African Descent, on the Conclusion of Its Official Visit to Germany, 20-27 February 2017. Berlin: UN Human Rights. http://www.ohchr.org/EN/NewsEvents/Pages/DisplayNews.aspx?NewsID=21233\&LangID= E.

Oosterveld, W., \& Galand, R. (2012). Justice Reform, Security Sector Reform and Local Ownership. Hague Journal on the Rule of Law, 4(1), 194-209. 
Ottaway, Marina. 2002. "Rebuilding State Institutions in Collapsed States." Development and Change 33 (5): 1001-1023. doi:10.1111/1467-7660.t01-1-00258.

Paffenholz, Thanja. 2010. "Civil Society and Peacebuilding." In Civil Society \& Peacebuilding: A Critical Assessment, edited by Thanja Paffenholz, 43-63. Boulder: Lynne Rienner Publishers.

Podder, Sukuanya. 2013. "Bridging the 'Conceptual-Contextual' Divide: Security Sector Reform in Liberia and UNMIL Transition." Journal of Intervention and Statebuilding 7(3): 353-380, doi: 10.1080/17502977.2013.770242.

Paris, Roland. 2009. "Understanding the 'Coordination' Problem in Postwar Statebuilding." In The Dilemmas of Statebuilding. Confronting the Contradictions of Postwar Peace Operations, edited by Timothy D. Sisk and Roland Paris, 53-78. London: Routledge.

Price, Megan, and Michael Warren. 2017. "Reimagining SSR in Contexts of Security Pluralism." Stability: International Journal of Security and Development 6 (1): 8. doi:10.5334/sta.555.

Rathmell, Andrew, ed. 2005. Developing Iraq's Security Sector: The Coalition Provisional Authority's Experience. Santa Monica, CA: Rand.

Richmond, Oliver. 2006. "The problem of peace: understanding the 'liberal peace'.” Conflict, Security \& Development 6(3): 291-314, doi: 10.1080/14678800600933480.

Richmond, Oliver. 2011. "De-romanticising the local, de-mystifying the international: hybridity in Timor Leste and the Solomon Islands." The Pacific Review 24(1): 115-136, doi: 10.1080/09512748.2010.546873.

Ross, Cody T. 2015. "A Multi-Level Bayesian Analysis of Racial Bias in Police Shootings at the CountyLevel in the United States, 2011-2014." Edited by Peter James Hills. PLOS ONE 10 (11): e0141854. doi:10.1371/journal.pone.0141854.

Rublee, Maria Rost. 2008. "Taking Stock of the Nuclear Nonproliferation Regime: Using Social Psychology to Understand Regime Effectiveness." International Studies Review 10 (3): 420-450. doi:10.1111/j.1468-2486.2008.00799.x.

Rublee, Maria Rost. 2009. Nonproliferation Norms: Why States Choose Nuclear Restraint. Studies in Security and International Affairs. Athens: University of Georgia Press.

Sabaratnam, Meera. 2017. Decolonising Intervention: International Statebuilding in Mozambique. Kilombo: International Relations and Colonial Questions. London; New York: Rowman \& Littlefield International.

Schroeder, Ursula C. 2010. "Measuring Security Sector Governance: A Guide to Relevant Indicators." Occasional Paper No. 20. Geneva: DCAF. https://www.dcaf.ch/measuring-security-sectorgovernance.

Schroeder, Ursula and Chappuis, Fairlie. 2014. "New Perspectives on Security Sector Reform: The Role of Local Agency and Domestic Politics." International Peacekeeping 21(2): 133-148, doi: 10.1080/13533312.2014.910401.

Schroeder, Ursula C., Fairlie Chappuis, and Deniz Kocak. 2014. "Security Sector Reform and the Emergence of Hybrid Security Governance.” International Peacekeeping 21 (2): 214-230. doi:10.1080/13533312.2014.910405.

Sedra, Mark. 2007. "Security Sector Reform in Afghanistan and Iraq: Exposing a Concept in Crisis." Journal of Peacebuilding \& Development 3 (2): 7-23. doi:10.1080/15423166.2007.486990145914.

Sedra, Mark. 2010. Introduction: the Future of Security Sector Reform. In The Future of Security Sector Reform, edited by Mark Sedra. Ontario: CIGI, 16-27. http://www.deslibris.ca/ID/225839.

Sedra, Mark. 2014. “An Uncertain Future for Afghanistan's Security Sector.” Stability: International Journal of Security \& Development 3 (1): 1-16. doi:10.5334/sta.ei.

Sedra, Mark. 2017. Security Sector Reform in Conflict-Affected Countries: The Evolution of a Model. New York: Routledge.

Sedra, Mark. 2018. "Adapting Security Sector Reform to Ground-Level Realities: The Transition to a Second-Generation Model." Journal of Intervention and Statebuilding 12(1): 48-63. doi: 10.1080/17502977.2018.1426383.

StabilisationUnit. 2014. Security Sector Stabilisation, Issues Note. Von Stabilisation Unit (UK): http://sclr.stabilisationunit.gov.uk/publications/stabilisation-series

True, J. 2012. The Political Economy of Violence Against Women. Cambridge: Cambridge University Press.

UN. 2014. Resolution 2151 (2014). UN Security Council Resolution. New York: United Nation Security Council. http://www.un.org/en/ga/search/view_doc.asp?symbol=S/RES/2151(2014). 
Wulf, Herbert. 2011. "Security Sector Reform in Developing and Transitional Countries Revisited." In Advancing Conflict Transformation. The Berghof Handbook II, edited by B. Austin, M. Fischer, H.J. Giessmann.Opladen/Framington Hills: Barbara Budrich Publishers. www.berghofhandbook.net. 